\title{
Severe skin reaction secondary to concomitant radiotherapy plus cetuximab
}

\author{
Bernhard Berger* and Claus Belka
}

\author{
Address: Department of Radiation Oncology, University of Tübingen, Hoppe-Seyler-Str. 3, 72076 Tübingen, Germany \\ Email: Bernhard Berger* - bernhard.berger@med.uni-tuebingen.de; Claus Belka - claus.belka@med.uni-tuebingen.de \\ * Corresponding author
}

Published: 28 January 2008

Radiation Oncology 2008, 3:5 doi:10.1186/1748-7/7X-3-5

This article is available from: http://www.ro-journal.com/content/3/I/5

(C) 2008 Berger and Belka; licensee BioMed Central Ltd.

This is an Open Access article distributed under the terms of the Creative Commons Attribution License (http://creativecommons.org/licenses/by/2.0), which permits unrestricted use, distribution, and reproduction in any medium, provided the original work is properly cited.
Received: 7 November 2007

Accepted: 28 January 2008

\begin{abstract}
The therapeutic use of monoclonal antibodies against the epidermal growth factor receptor (EGFR) is specifically associated with dermatologic reactions of variable severity. Recent evidence suggests superiority of the EGFR inhibitor (EGFRI) cetuximab plus radiotherapy compared to radiotherapy alone in patients with squamous cell carcinoma of the head and neck. Although not documented in a study population, several reports indicate a possible overlap between radiation dermatitis and the EGFRI-induced skin rash. We here present a case of severe skin reaction secondary to the addition of cetuximab to radiotherapy.
\end{abstract}

\section{Findings}

A 56-year-old woman with squamous cell cancer of the head and neck received primary chemoradiation at our institution. Due to thrombocytopenia, chemotherapy had to be stopped early and was replaced by the EGFR inhibitor cetuximab. In a close temporal relationship to the first dose, exacerbation of a pre-existing grade 1 radiation erythema occurred within the high-dose radiation portals. Clinically, features of both the EGFRI-induced acne-like rash and radiation dermatitis coexisted within the irradiated fields. Combined EGFRI-radiotherapy was continued under close clinical surveillance without worsening of the skin reaction. The case presented here corresponds to similar experience which is increasingly published. Clinicians should be aware of the possibly severe cumulation of dermatotoxic effects in this specific therapeutic setting.

\section{Background}

Contemporarily, there is increasing evidence supporting the concomitant use of cetuximab, a monoclonal antibody against the epidermal growth factor receptor
(EGFR), in addition to high-dose radiotherapy in primary treatment concepts of head and neck cancer [1]. In comparison to conventional chemotherapy, molecularly targeted agents reveal lower haematological toxicity. However, some specific side-effects such as allergic rashes and skin reactions may limit the therapeutic use and compromise the individual patient's compliance [2].

With respect to skin reactions secondarily to the administration of EGFR inhibitors (EGFRI), pruritic follicular eruptions with either pustular or maculopapular appearance are most common with an estimated occurrence in $>70 \%$ of patients [2-4]. Although acne-specific features such as comedones or microbial superinfection are lacking, the morphology is usually referred to as acneiform. Correspondingly, the clinical symptomatic is acne-like with a characteristic distribution in seborrhoeic areas (face, V-shaped neckline, upper torso). Histopathological analyses show enlargement of follicles with suppurative folliculitis and follicular plugging by keratin as conse- 
quence of the altered keratinocyte differentiation and increased apoptosis by the EGFR blockade [5].

Apparently, there is a great diversity of morphologic manifestations, and the majority of patients will experience only mild skin symptoms. However, severe reactions have been described in up to $10 \%$ of patients (grade $3 / 4$ according to the common toxicity criteria) $[3,6,7]$. There is only few information available concerning possible risk factors as well as interferences with other dermatotoxic factors as, for example, concomitant radiotherapy.

\section{Case presentation}

We report on a 56-year-old woman suffering from a squamous-cell carcinoma of the right base of tongue, $3 \times 5 \mathrm{~cm}$ in diameter. The patient declared alcohol abuse 10 years ago, and had Child-Pugh class A liver cirrhosis. Computed tomographic (CT) scanning of the whole body revealed a stage IVA disease ( $\mathrm{CT} 2 \mathrm{~N} 2 \mathrm{cM} 0$ ). The patient was scheduled for primary hyperfractionated accelerated chemoradiation according to the German Cancer Society 95-06 schedule [8]. Radiotherapy consisted of a three-dimensional conformal technique with a concomitant boost to the primary tumour and upper neck by lateral opposed portals (72.0 Gy/45 fractions/42 days). 49.6 Gy in 29 fractions were given to the cervical lymphatics and the lower anterior neck.

In parallel to radiotherapy, systemic therapy with continuous infusional 5-fluorouracil $\left(600 \mathrm{mg} \mathrm{m}^{-2}\right.$, days 1-5) and mitomycin $\mathrm{C}\left(10 \mathrm{mg} \mathrm{m}^{-2}\right.$, days 5 and 36) was started. However, due to progressive grade 2 thrombocytopenia, chemotherapy had to be stopped on day 4 . In the progress of radiotherapy, oral grade 2 mucositis developed in week 3 , and the patient got a gastrostomy placed to ensure adequate fluid and nutrition supply. To that time, the external facial and cervical skin reaction consisted of a grade 1 diffuse erythema without ulceration or epitheliolyses. The patient's regular medications were morphine sulfate and metamizole for pain relief; no other acne-inducing drugs were used.

Due to the unforeseen stop of chemotherapy, a lack of therapeutic efficacy was assumed and, therefore, parallel treatment with cetuximab was offered according to the published protocol [1]. After informed consent, the patient received the first dose of cetuximab $\left(250 \mathrm{mg} \mathrm{m}^{-2}\right)$ with a radiation dose of 44.0 Gy being applied. Within hours after the first cetuximab infusion, vesicular and pustular eruptions developed on both cheeks that evolved into haemorrhagic lesions during the following days (Fig. 1 ). This cutaneous exacerbation was well confined to the opposed lateral oropharyngeal portals (Fig. 2). In contrast, the lower cervical skin and neckline showed only a

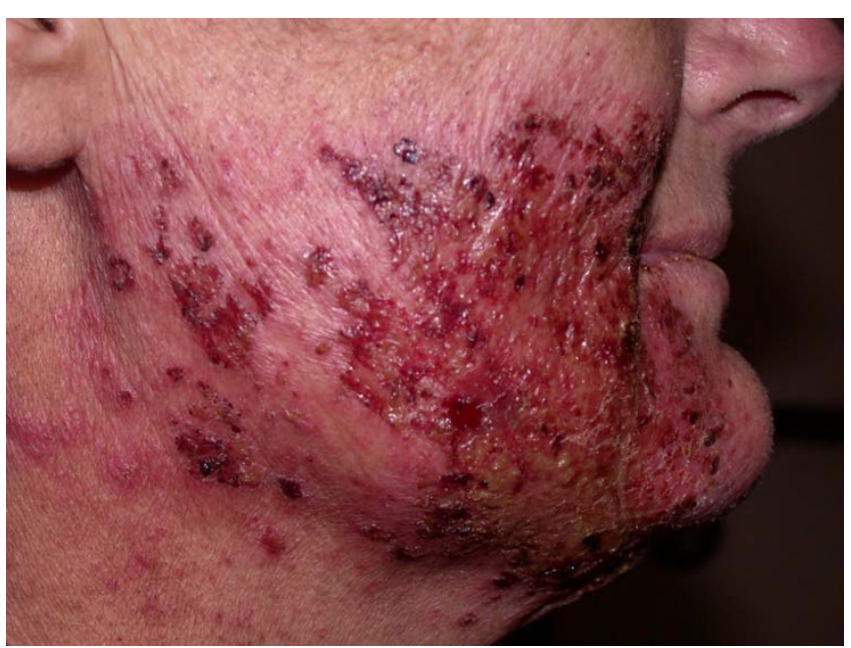

\section{Figure I}

Exacerbated radiation dermatitis after cetuximab treatment.

minor erythema without ulceration or folliculitis. Hair or nail changes were not reported.

The patient got an oral antihistamine for the relief of pruritus, and a moisturising skin cream with antiseptic ingredients was applied for topical treatment. Given the stable development in the following, no other symptomatic measures were taken. Laboratory findings were normal without inflammatory changes. Herpes simplex (HSV-1)

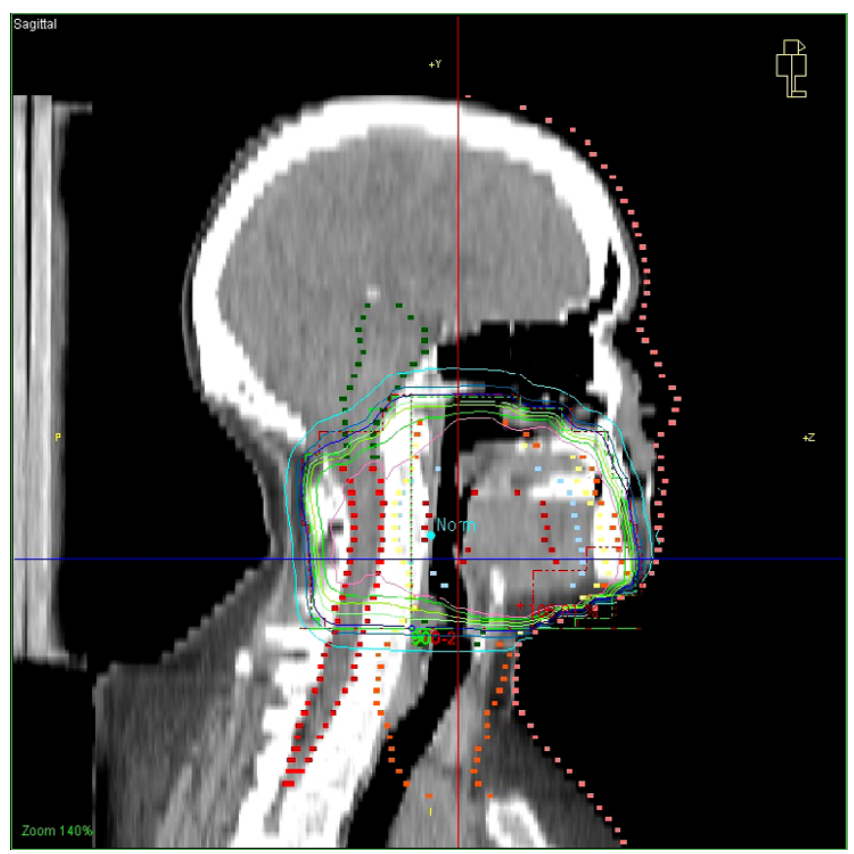

Figure 2

Corresponding digitally reconstructed radiograph of the radiation portals. 
infection was ruled out by negative polymerase chain reaction findings for HSV-1 DNA, performed out of vesicular fluid as well as saliva smears. Serological tests for HSV-1 antibodies revealed positive IgG titers, but were negative for IgM.

The patient agreed to receive two further cetuximab infusions on a weekly basis. The daily visit showed no worsening of the skin reaction. At the end of treatment, the clinical findings were stable with clusters of confluent haemorrhagic crusts on both cheeks.

At follow-up six weeks after completion of therapy, the skin manifestations had declined to asymptomatic residual crusts in small areas. The patient proceeded to apply regularly moisturising emollients. Another six weeks later, intact dry skin had regenerated, but with hypopigmented stains indicating the former necrotic lesions. Repeated CT scanning at that time revealed a complete tumour response.

\section{Discussion}

The skin rash by EGFRI is thought to be the direct consequence of the EGFR blockade in basal epidermal keratinocytes as well as the outer root sheath of hair follicles, leading to a local growth arrest and consecutive inflammation. Its occurrence may be a pharmacodynamic marker of the drug action and has been proposed as surrogate parameter of tumour response $[9,10]$.

EGFRI are increasingly used in parallel to, or, at least, in short sequence to radiotherapy. For example, combined treatment with cetuximab and radiotherapy has been shown to improve locoregional control in patients with squamous cell carcinoma of the head and neck in a phase 3 trial [1]. Whereas the administration of cetuximab led to a significant amount of EGFRI-induced skin rashes in the combined treatment group ( $8.2 \%$ vs. $0.5 \%, \mathrm{p}<0.001)$, no statistically significant exacerbation of radiation dermatitis was reported (23 vs. $18 \%$ grade $3-5$ reactions, $\mathrm{p}=$ $0.27)$.

In recent times, however, accumulating case reports reveal grade $3 / 4$ skin reactions within radiation fields in combined treatment regimens [11-14]. The clinical localization suggests a correlation with the radiation dose as well as the former presence of intact pilosebaceous skin areas. The underlying pathomechanism remains unclear, but a synergistic inflammatory effect of both the cutaneous EGFR blockade and radiation seems likely. Accordingly, sparing of an EGFRI-induced rash has been reported in areas of soft tissue fibrosis, where previous radiotherapy has depleted skin glands and follicles [15].
The patient presented here developed ulcerative and haemorrhagic dermatitis in a close temporal relationship to the first application of cetuximab. Since we did not perform a skin biopsy, microscopic appearance and grading of this reaction remain vague. However, the clinical impression was comparable to those cases verified as grade 4 epidermal necrosis by histological analysis [11].

Most recently, first consensus guidelines for the treatment of cutaneous side-effects in combined EGFRI-radiotherapy have been published [16]. Based on the grade of the skin toxicity, treatment is adapted to the recommendations for EGFR-related rashes and radiation dermatitis. In our patient, there was a stable development of the skin reaction despite continuation of cetuximab therapy, which corresponds to reports on spontaneous resolution of skin rashes in EGFRI treatment alone [3]. However, this may be an exceptional event. In general, clinicians should be alert to the possibly severe skin toxicity after addition of EGFRI to radiotherapy. For appropriate patients, a close surveillance strategy may help to prevent further complications as well as an early treatment interruption.

\section{Competing interests}

The author(s) declare that they have no competing interests.

\section{Authors' contributions}

$\mathrm{BB}$ reviewed the patient data and drafted the manuscript, CB participated in its concept and design. Both authors read and approved the final version.

\section{Acknowledgements}

Written informed consent was obtained from the patient for publication of this case report and any accompanying images. A copy of the written consent is available for review by the Editor-in-Chief of this journal.

\section{References}

I. Bonner JA, Harari PM, Giralt J, Azarnia N, Shin DM, Cohen RB, Jones CU, Sur R, Raben D, Jassem J, Ove R, Kies MS, Baselga J, Youssoufian $\mathrm{H}$, Amellal N, Rowinsky EK, Ang KK: Radiotherapy plus cetuximab for squamous-cell carcinoma of the head and neck. $N$ Engl J Med 2006, 354:567-578.

2. Lacouture ME: Mechanisms of cutaneous toxicities to EGFR inhibitors. Nat Rev Cancer 2006, 6:803-8I2.

3. Jacot W, Bessis D, Jorda E, Ychou M, Fabbro M, Pujol JL, Guillot B: Acneiform eruption induced by epidermal growth factor receptor inhibitors in patients with solid tumours. $\mathrm{Br}$ J Dermatol 2004, I 5 I:238-24I.

4. Segaert S, Tabernero J, Chosidow O, Dirschka T, Elsner J, Mancini L, Maughan T, Morere JF, Santoro A, Sobrero A, Van Cutsem E, Layton $A$ : The management of skin reactions in cancer patients receiving epidermal growth factor receptor targeted therapies. J Dtsch Dermatol Ges 2005, 3:599-606.

5. Albanell J, Rojo F, Averbuch S, Feyereislova A, Mascaro JM, Herbst R, LoRusso P, Rischin D, Sauleda S, Gee J, Nicholson RI, Baselga J: Pharmacodynamic studies of the epidermal growth factor receptor inhibitor ZDI839 in skin from cancer patients: histopathologic and molecular consequences of receptor inhibition. J Clin Oncol 2002, 20: I I0-124.

6. Saltz LB, Meropol NJ, Loehrer PJ Sr, Needle MN, Kopit J, Mayer RJ: Phase II trial of cetuximab in patients with refractory color- 
ectal cancer that expresses the epidermal growth factor receptor. J Clin Oncol 2004, 22: I20I-I208.

7. Cunningham $D$, Humblet $Y$, Siena $S$, Khayat $D$, Bleiberg $H$, Santoro $A$, Bets D, Mueser M, Harstrick A, Verslype C, Chau I, Van Cutsem E: Cetuximab monotherapy and cetuximab plus irinotecan in irinotecan-refractory metastatic colorectal cancer. N Engl J Med 2004, 35 I:337-45.

8. Budach V, Stuschke M, Budach W, Baumann M, Geismar D, Grabenbauer G, Lammert I, Jahnke K, Stueben G, Herrmann T, Bamberg M, Wust $P$, Hinkelbein W, Wernecke KD: Hyperfractionated accelerated chemoradiation with concurrent fluorouracil-mitomycin is more effective than dose-escalated hyperfractionated accelerated radiation therapy alone in locally advanced head and neck cancer: final results of the radiotherapy cooperative clinical trials group of the German Cancer Society 95-06 Prospective Randomized Trial. J Clin Oncol 2005, 23: I I25-II35.

9. Rowinsky EK, Schwartz GH, Gollob JA, Thompson JA, Vogelzang NJ, Figlin R, Bukowski R, Haas N, Lockbaum P, Li YP, Arends R, Foon KA, Schwab G, Dutcher J: Safety, pharmacokinetics, and activity of ABX-EGF, a fully human anti-epidermal growth factor receptor monoclonal antibody in patients with metastatic renal cell cancer. I Clin Oncol 2004, 22:3003-3015.

10. Pérez-Soler R, Chachoua A, Hammond LA, Rowinsky EK, Huberman $M$, Karp D, Rigas J, Clark GM, Santabárbara P, Bonomi P: Determinants of tumor response and survival with erlotinib in patients with non-small-cell lung cancer. J Clin Oncol 2004, 22:3238-3247.

II. Budach W, Bölke E, Homey B: Severe cutaneous reaction during radiation therapy with concurrent cetuximab. $N$ Engl J Med 2007, 357:5I4-5I5.

12. Mydin AR, Armstrong JG: Acneiform rash secondary to cetuximab plus head and neck radiotherapy. Radiother Oncol 2007 85: 171 .

13. Lacouture ME, Hwang C, Marymont MH, Patel J: Temporal dependence of the effect of radiation on erlotinib-induced skin rash. I Clin Oncol 2007, 25:2I 40.

14. Bonner JA, Ang K: More on severe cutaneous reaction with radiotherapy and cetuximab. N Eng/J Med 2007, 357: 1872-1873.

15. Mitra SS, Simcock R: Erlotinib induced skin rash spares skin in previous radiotherapy field. J Clin Oncol 2006, 24:28-29.

16. Bernier J, Bonner J, Vermorken JB, Bensadoun RJ, Dummer R, Giralt J, Kornek G, Hartley A, Mesia R, Robert C, Segaert S, Ang KK: Consensus guidelines for the management of radiation dermatitis and coexisting acne-like rash in patients receiving radiotherapy plus EGFR inhibitors for the treatment of squamous cell carcinoma of the head and neck. Ann Oncol 2008 , 19:142-149.

\section{Publish with Bio Med Central and every scientist can read your work free of charge}

"BioMed Central will be the most significant development for disseminating the results of biomedical research in our lifetime. "

Sir Paul Nurse, Cancer Research UK

Your research papers will be:

- available free of charge to the entire biomedical community

- peer reviewed and published immediately upon acceptance

- cited in PubMed and archived on PubMed Central

- yours - you keep the copyright
BioMedcentral 